\title{
ANALISIS BUDIDAYA PEMBESARAN IKAN PATIN (Pangasius sp.) DI KECAMATAN TALANG KELAPA KABUPATEN BANYUASIN
}

\section{Analysis of Catfish (Pangasius sp.) Enlargement culture in Talang Kelapa Subdistrict, Banyuasin Regency}

\author{
Leza Agriansa ${ }^{1}$, Sumantriyadi², dan Lia Perwita Sari ${ }^{2 *}$ \\ ${ }^{1}$ Program Studi Ilmu Perikanan, Fakultas Perikanan Universitas PGRI Palembang \\ ${ }^{2}$ Program Studi Budidaya Ikan Fakultas Perikanan Universitas PGRI Palembang \\ * corresponding author: lehakps@yahoo.co.id
}

\begin{abstract}
ABSTRAK
Ikan Patin (Pangasius sp.) merupakan salah satu jenis ikan air tawar yang memiliki nilai ekonomis penting dalam dunia akuakultur. Tujuan penelitian ini untuk mengetahui parameter kualitas air dan menganalisis seberapa besar total biaya produksi dan tingkat pendapatan pada usaha budidaya pembesaran ikan Patin. Penelitian ini dilakukan pada bulan Mei dan Juni 2019. Pendekatan penelitian ini adalah studi kasus, dengan teknik pengumpulan data melalui observasi langsung, pengamatan, wawancara dan studi pustaka dengan menggunakan metode analisa data mix method yaitu kualitatif dan kuantitatif. Hasil penelitian menunjukkan nilai kualitas air dengan kisaran suhu $27-33^{\circ} \mathrm{C}$ dan kisaran $\mathrm{pH}$ pada nilai 6-8. Biaya produksi pada usaha budidaya pembesaran ikan Patin dapat disesuaikan dengan kebutuhan yang diinginkan. Untuk biaya investasi berkisar antara Rp. 18.307.500 hingga Rp. 37.091.875 untuk biaya tetap berkisar antara Rp. 484.667 hongga Rp. 1.527.083 untuk biaya variabel pada kisaran Rp. 49.733 .750 hingga Rp. 163.878 .750 per siklus dengan penerimaan antara Rp. 87.300.000 hingga Rp. 235.212.500 per siklus, pendapatan yang diperoleh berkisar antara Rp. 18.537.633 hingga Rp. 69.806 .666 per siklus.
\end{abstract}

Kata kunci: Ikan Patin, budidaya, kualitas air, biaya

\begin{abstract}
Catfish (Pangasius sp.) is one type of freshwater fish that has important economic value in aquaculture. The purpose of the study was to determine the parameters of water quality and analyze how much the total production cost and income level in the business of growing Patin fish. This research was conducted in May and June 2019. The approach of this study is a case study, with data collection techniques through direct observation, observation, interviews and literature study using the method of mix method data analysis namely qualitative and quantitative. The results showed the value of water quality with temperatures range of $27-33^{\circ} \mathrm{C}$ and $\mathrm{pH}$ range at values 6-8. Production costs in the business of cultivating Patin fish can be adjusted to the desired needs. For investment costs ranging from Rp.18.307.500 up to Rp. 37.091.875 for fixed costs ranging from Rp. 484.667 up to Rp. 1.527.083 for variable costs in the range of Rp.49.733.750 up to Rp.163.878.750 per cycle with receipts between Rp.87.300.000 up to Rp.235.212.500 per cycle, the income earned is around Rp.18.537.633 up to Rp.69.806.666 per cycle.
\end{abstract}

Key words: Catfish, culture, water quality, costs 


\section{PENDAHUUAN}

Ikan Patin (Pangasius sp) merupakan salah satu jenis ikan air tawar yang memiliki nilai ekonomis penting dalam dunia akuakultur.. Departemen perikanan dan akuakultur FAO (Food and Agriculture Organization) menempatkan ikan Patin di urutan kelima setelah ikan mas (Cyprinus carpio), ikan nila (Oreochromis niloticus), ikan lele (Clarias sp) dan ikan gurami (Osphronemus gouramy) (Ghufran, 2010). Tidak mengherankan jika saat ini banyak rumah makan atau restoran yang menyediakan olahan ikan Patin sebagai menu utamanya salah satunya pindang ikam Patin. Kebutuhan ikan Patin di mancanegara menunjukkan trend positif, seperti di Tiongkok. Impor ikan Patin di negeri tirai bambu tersebut tumbuh pesat hingga mencapai 34.400 ton per tahun. Angka tersebut disusul oleh Thailand yang mencapai 19.200 ton per tahunnya. Di Amerika Latin, impor ikan Patin juga menunjukkan kenaikan hingga 12,3\%. Meningkatnya kebutuhan ikan Patin di beberapa negara tersebut, merupakan kesadaran masyarakat dalam memenuhi gizi dan protein. Hal tersebut dapat dijadikan sebagai peluang bagi Indonesia untuk menduniakan ikan Patin lokal. Wilayah Sumatera menyumbang 68,07 \% dari produksi nasional, dengan rincian wilayah Sumatera Selatan penyumbang terbesar yakni mencapai 47,23\% (Kementrian Kelautan dan Perikanan, 2018). Provinsi Sumatera Selatan merupakan daerah penghasil produksi ikan Patin terbesar di Indonesia dan Kabupaten Banyuasin menjadi sentra produksi budidaya ikan Patin tingkat nasional dan Provinsi. dapat dilihat pada Tabel 1 :

Tabel 1. Sentra Produksi Budidaya Ikan Patin Kabupaten/Kota Tahun 2015

\begin{tabular}{|c|c|c|c|}
\hline No & Provinsi & Kabupaten/Kota & Produksi (Ton) \\
\hline \multirow[t]{5}{*}{1} & Sumatera Selatan & 1. Banyuasin & 36.761 .40 \\
\hline & & 2. Ogan Komering Ulu Timur & 35.053 .26 \\
\hline & & 3. Ogan Komering Ilir & 25.017.20 \\
\hline & & 4. Musi Banyuasin & 17.059 .80 \\
\hline & & 5. Ogan Ilir & 15.399 .80 \\
\hline \multirow[t]{5}{*}{2} & Kalimantan Selatan & 1. Banjar & 14.141 .30 \\
\hline & & 2. Hulu Sungai Utara & 10.860 .40 \\
\hline & & 3. Hulu Sungai Selatan & 4.529 .90 \\
\hline & & 4. Tabalong & 1.301 .70 \\
\hline & & 5. Kota Banjar Baru & 678.90 \\
\hline \multirow[t]{5}{*}{3} & Kalimantan Tengah & 1. Kapuas & 8.293 .34 \\
\hline & & 2. Kota Palangkaraya & 5.991 .98 \\
\hline & & 3. Seruyan & 3.206 .72 \\
\hline & & 4. Kota Waringin Timur & 2.159 .12 \\
\hline & & 5. Barito Utara & 1.624 .00 \\
\hline
\end{tabular}

Sumber: Buku Statistik Perikanan Budidaya Indonesia, 2015

Untuk di wilayah Kabupaten Banyuasin produksi ikan Patin setiap harinya dapat menghasilkan rata-rata 2030 ton, yang berasal dari Kecamatan Talang Kelapa. Disamping untuk memenuhi kebutuhan pasar lokal, hasil produksi budidaya ikan Patin Kabupaten Banyuasin juga didistribusikan ke beberapa daerah di sekitarnya seperti Palembang (Pasar Induk Jakabaring), Prabumulih, Muara Enim, 
Baturaja, Sekayu, bahkan Lubuk Linggau dan Musi Rawas (Dinas Perikanan Kabupaten Banyuasin, 2017). Penelitian ini bertujuan untuk mengetahui parameter kualitas air dan menganalisis seberapa besar total biaya produksi dan tingkat pendapatan pada budidaya pembesaran ikan Patin di Kecamatan Talang Kelapa Kabupaten Banyuasin.

\section{METODE PENELITIAN}

Penelitian ini dilaksanakan di Kecamatan Talang Kelapa Kabupaten Banyuasin.Waktu penelitian dilakukan bulan Mei dan Juni 2019. Penentuan lokasi ini secara sengaja (purposive) dengan pertimbangan bahwa lokasi ini merupakan sentra produksi budidaya ikan air tawar terutama ikan Patin (Pangasius sp) di Kabupaten Banyuasin Sumatera Selatan. Metode pendekatan penelitian yang digunakan adalah studi kasus dengan satuan kasusnya adalah usaha budidaya pembesaran ikan Patin.

Teknik pengumpulan data yang diperoleh melalui teknik observasi langsung melalui pengamatan, wawancara dan studi pustaka yang disertai pencatatan terhadap keadaan atau perilaku objek sasaran. Adapun penelitian ini menggunakan rumus Slovin karena dalam penarikan sampel, jumlahnya harus representative agar hasil penelitian dapat digeneralisasikan dan perhitungannya tidak memerlukan tabel jumlah sampel, namun dapat dilakukan dengan rumus dan perhitungan sederhana.

Rumus Slovin untuk menentukan sampel adalah sebagai berikut :

$$
n=\frac{N}{1+N(e)^{2}}
$$

Keterangan:

$n=$ Ukuran sampel/jumlah responden

$N=$ Ukuran populasi

$e=$ Presentase kelonggaran ketelitian kesalahan pengambilan sampel yang masih bisa ditolerir; $\mathrm{e}=0,1$
Dalam rumus Slovin ada ketentuan sebagai berikut :

$\begin{aligned} \text { Nilai e }= & 0,1 \quad(10 \%) \text { untuk populasi } \\ \text { dalam jumlah besar } & \\ \text { Nilai e }= & \begin{array}{c}0,2(20 \%) \text { untuk populasi } \\ \text { dalam jumlah kecil }\end{array}\end{aligned}$

Jadi rentang sampel yang dapat diambil dari teknik Solvin adalah antara 10-20\% dari populasi penelitian. Kategori untuk menjadi responden, peneliti membatasi sampel dengan batasan pada status kepemilikan lahan pribadi bukan sewa, jenis kolam yang digunakan merupakan kolam tanah atau galian dengan meliputi prosedur kegiatan budidaya dari awal tebar sampai panen dan jenis usaha yang dilakukan ialah pembesaran ikan Patin yang usahanya telah berjalan minimal 2 tahun.

Menurut data dari Dinas Perikanan Kabupaten Banyuasin jumlah kelompok pembudidaya ikan yang ada di Kecamtan Talang Kelapa berjumlah 17 kelompok dengan berbagai kegiatan usaha budidaya perikanan. Namun, hanya 7 kelompok yang melakukan kegiatan usaha budidaya pembesaran ikan Patin. Dari 7 kelompok tersebut jumlah totalnya sebanyak 82 orang. Maka sampel yang diambil sebanyak 18 orang atau $21,9 \%$ dari jumlah populasi. Jenis data yang dikumpulkan mencakup data primer dan data sekunder Metode analisis data yang digunakan adalah mix method yaitu metode kualitatif dan kuantitatif.

Metode kualitatif dilakukan secara deksriptif dalam rangka untuk memastikan dan juga menggambarkan karakteristik dari peubahpeubah penting situasi. Tujuan dari penelitian deskriptif adalah untuk menggambarkan aspekaspek yang relevan terhadap fenomena yang menarik dari suatu individu maupun organisasi (Sekaran (2000) dalam Triyanti, et al. (2015)). 


\section{Pengukuran Kualitas Air}

Pengukuran kualitas air dilakukan pada media pemeliharaan ikan Patin di kolam pemeliharaan yaitu pada kolam awal tebar benih, kolam pemeliharaan ikan Patin yang telah berumur 3 bulan dan kolam ikan Patin yang siap panen. Pengambilan sampel dilakukan pada waktu pagi hari pukul $07.00 \mathrm{WIB}$, siang hari pukul 12.00 WIB dan sore hari pukul 17.00 WIB setiap satu kali. Parameter kualitas air yang diuji adalah, suhu dan $\mathrm{pH}$.

\section{Pengukuran Suhu}

Pada pengukuran suhu, alat yang perlu dilakukan adalah termometer, pengukuran suhu dilakukan pada air kolam pemeliharaan. Cara kerja untuk pengukuran suhu adalah sebagai berikut : masukkan termometer kedalam air kolam yang akan diukur suhunya selama 5 menit. Lalu lihat skala yang terdapat pada termometer dan catat hasil pengamatan.

\section{Pengukuran $\mathrm{pH}$}

Cara menguji $\mathrm{pH}$ yaitu dengan cara memasukan kertas lakmus kedalam air sampel dan selanjutnya membandingkan kertas lakmus yang sudah dicelupkan ke air sampel dengan indikator $\mathrm{pH}$ dan mencatat hasilnya.

\section{Analisa Usaha}

Analisa usaha yang dilakukan dalam penelitian ini antara lain:

\section{Analisa Biaya Produksi}

Menurut Suratiyah (2015) untuk menghitung besarnya biaya total (Total Cost) diperoleh dengan cara menjumlahkan biaya tetap (Fixed Cost/ FC) dengan biaya variabel (Variable Cost) dengan rumus:

$\mathrm{TC}=\mathrm{FC}+\mathrm{VC}$

Keterangan :

$$
\begin{aligned}
\mathrm{TC}= & \text { Total Cost }(\text { Biaya Total })(\mathrm{Rp}) \\
\mathrm{FC}= & \text { Fixed Cost }(\text { Biaya Tetap Total })(\mathrm{Rp}) \\
\mathrm{VC}= & \text { Variable Cost }(\text { Biaya Variabel }) \\
& (\mathrm{Rp})
\end{aligned}
$$

\section{Analisa Penerimaan}

Menurut Suratiyah (2015) secara umum perhitungan penerimaan total (Total Revenue/TR) adalah perkalian antara jumlah produksi (Y) dengan harga jual (Py) dan dinyatakan dengan rumus sebagai berikut:

$$
\mathrm{TR}=\mathrm{Py} \cdot \mathrm{Y}
$$

Keterangan :

$$
\begin{aligned}
\mathrm{TR}= & \text { Total Revenue } / \text { Penerimaan Total } \\
& (\mathrm{Rp}) \\
\mathrm{Py}= & \operatorname{Harga} \text { produk }(\mathrm{Rp}) \\
\mathrm{Y}= & \text { Jumlah produksi }(\mathrm{Kg})
\end{aligned}
$$

\section{Analisis Pendapatan}

Menurut Suratiyah (2015) pendapatan adalah selisih antara penerimaan (TR) dan biaya total (TC) dan dinyatakan dengan rumus:

$$
\mathrm{I}=\mathrm{TR}-\mathrm{TC}
$$

Keterangan :

I = Income (Pendapatan) $(\mathrm{Rp})$

$\mathrm{TR}=$ Total Revenue $/$ Penerimaan Total (Rp)

$\mathrm{TC}=$ Total Cost (Biaya Total) (Rp)

\section{Analisis $R / C$}

Menurut Suratiyah (2015), R/C adalah perbandingan antara penerimaan dengan biaya total.

$$
\mathrm{R} / \mathrm{C}=\frac{\text { Penerimaan total }(\mathrm{TR})}{\text { Biaya total }(\mathrm{TC})}
$$

Keterangan :

$\mathrm{R} / \mathrm{C}=$ Revenue/Cost

$\mathrm{TR}=$ Penerimaan Total $(\mathrm{Rp})$

$\mathrm{TC}=$ Total Cost $($ Biaya Total $)(\mathrm{Rp})$

Ada tiga kriteria dalam perhitungannya, yaitu:

1. Apabila $\mathrm{R} / \mathrm{C}>1$ artinya usahatani tersebut menguntungkan.

2. Apabila $\mathrm{R} / \mathrm{C}=1$ artinya usahatani tersebut impas. 
3. Apabila $\mathrm{R} / \mathrm{C}<1$ artinya usahatani tersebut rugi.

\section{Analisis B/C}

Benefit/Cost Ratio merupakan alat analisa untuk mengukur tingkat kelayakan di dalam proses produksi usahatani, (Soekartawi (1995) dalam Rizki, et al. (2017)).

$$
(B / C)=\frac{B}{C}
$$

Keterangan :

$\mathrm{B} / \mathrm{C}=$ Benefit $/$ Cost

$\mathrm{B}=$ Pendapatan (Benefit) (Rp)

$\mathrm{C}$ = Besarnya biaya yang dikeluarakan (Rp)

Ada tiga kriteria dalam perhitungannya, yaitu :

1. Jika B/C Ratio >0, maka usaha yang dijalankan mengalami keuntungan atau layak untuk dikembangkan.

2. B/C Ratio < 0, maka usaha tersebut mengalami kerugian atau tidak layak untuk dikembangkan.

3. Jika B/C Ratio = 0 maka usaha berada pada titik impas (Break Even Point).

\section{Break Even Point}

Break Even Point dapat dituliskan dalam bentuk produksi dan harga dengan persamaan (Mahyuddin, 2013) :

$$
\begin{aligned}
& \text { BEP Produksi }=\frac{\mathrm{vC}}{P} \\
& \text { BEP Harga }=\frac{\mathrm{VC}}{\mathrm{Y}}
\end{aligned}
$$

Keterangan :

$$
\begin{aligned}
& \mathrm{VC}=\text { Total Biaya Variabel } \\
& (\mathrm{Rp} / \text { Siklus/Kg) } \\
& \mathrm{P} \quad=\text { Harga Jual Per } \mathrm{Kg}(\mathrm{Rp} / \mathrm{Kg}) \\
& \mathrm{Y}=\text { Jumlah Produksi }(\mathrm{Kg})
\end{aligned}
$$

\section{HASIL DAN PEMBAHASAN Keadaan Umum}

Kecamatan Talang Kelapa merupakan salah satu kecamatan di Kabupaten Banyuasin dengan luas wilayah 439.43 kilometer persegi dan berpenduduk sekitar 133.265 jiwa. Letak Kecamatan Talang Kelapa berbatasan langsung dengan tujuh Kecamatan, sebelah utara berbatasan Kecamatan Tanjung Lago dan Sako Palembang, sebelah selatan Kecamatan Rantau Bayur dan Kecamatan Gandus Palembang, sebelah barat Kecamatan Sembawa, sebelah timur Kecamatan Sukarami dan Alang-Alang Lebar Palembang.

Pusat pemerintahan Kecamatan Talang Kelapa berada di Kelurahan Sukajadi, sedangkan titik keramaian berada di dua wilayah, Kelurahan Sukajadi dan Kelurahan Kenten, hal ini dikarenakan di dua wilayah ini terdapat pusat pemukiman dan pertokoan, dan memiliki akses yang mudah seperti Jalan Palembang - Betung di Sukajadi dan Jalan Pangeran Ayin di Kelurahan Kenten. Kedua jalan ini langsung menuju kota Palembang. Kecamatan Talang Kelapa, yakni jalur urat nadi perekonomian perbatasan mulai dari kawasan Sukajadi ruas kilometer 13 sampai kilometer 20, Jalan Palembang - Betung.

Adapun di wilayah Kenten Palembang terdapat ruas Jalan Pangeran Ayin yang menghubungkan langsung dibagian wilayah kota Palembang, dan satu lagi kawasan yang baru berkembang, yakni wilayah Gasing yang merupakan kawasan industri di Jalan Poros Tanjung Api-api. 
Tabel 2. Daftar Nama Kelurahan dan Desa Di Kecamatan Talang Kelapa

\begin{tabular}{lll}
\hline Kecamatan & No & Desa/Kelurahan \\
\hline Talang Kelapa & 1 & Kelurahan Sukajadi \\
2 & Kelurahan Tanah Mas \\
3 & Kelurahan Sukomoro \\
4 & Kelurahan Air Batu \\
5 & Kelurahan Talang Keramat \\
6 & Kelurahan Kenten \\
7 & Kelurahan Kenten Laut \\
8 & Desa Gasing \\
9 & Desa Pangkalan Benteng \\
10 & Desa Sungai Rengit \\
11 & Desa Sungai Rengit Murni \\
12 & Desa Talang Buluh \\
\hline
\end{tabular}

Sumber: Kab. Banyuasin dalam angka 2017:30

Tabel 3. Jumlah Kependudukan dan Ketenagakerjaan di Kecamatan Talang Kelapa

\begin{tabular}{lcc}
\hline Desa/Kelurahan & Jumlah Keluarga & Jumlah keluarga Pertanian \\
\hline Sukajadi & 6670 & 500 \\
Tanah Mas & 4456 & 95 \\
Sukomoro & 4036 & 575 \\
Air Batu & 2947 & 150 \\
Talang Keramat & 1565 & 695 \\
Kenten & 5447 & 248 \\
Kenten Laut & 2330 & 285 \\
Gasing & 1736 & 100 \\
Pangkalan Benteng & 808 & 242 \\
Sungai Rengit & 1678 & 1500 \\
Sungai Rengit Murni & 1002 & 649 \\
Talang Buluh & 2573 & 563
\end{tabular}

Sumber: Kecamatan Talang Kelapa dalam angka, 2018: 5-7

Dalam penelitian ini penulis telah mengadakan berbagai usaha seperti obesevasi lapangan, wawancara dan studi pustaka dengan hasil sebagai berikut:

Tabel 4. Lokasi Responden

\begin{tabular}{lcc}
\hline Desa/Kelurahan & Responden (jiwa) & Persentase (\%) \\
\hline Talang Buluh & 2 & 11 \\
Sungai Rengit & 5 & 28 \\
Air Batu & 2 & 11 \\
Sukomoro & 4 & 22.2 \\
Sukajadi & 2 & 11 \\
Sungai Rengit Murni & 3 & 16.6 \\
& & \\
\hline Jumlah & 18 & 100 \\
Sumber: Data primer hasil penelitian, 2019 &
\end{tabular}


Dari Tabel 4 di atas menunjukkan bahwa tempat lokasi setiap responden merupakan wilayah administrasi Kecamatan Talang Kelapa. Dimana Desa Sungai Rengit menjadi sampel terbanyak yaitu 28\%, Kelurahan Sukomoro 22,2\%, Desa Sungai Rengit Murni 16,6\%, Kelurahan Sukajadi, Kelurahan Air Batu dan Desa Talang Buluh masing-masing $11 \%$.

Tabel 5. Umur Responden

\begin{tabular}{lccc}
\hline No & Umur (tahun) & $\begin{array}{c}\text { Responden } \\
\text { (Jiwa) }\end{array}$ & $\begin{array}{c}\text { Persentase } \\
(\boldsymbol{\%})\end{array}$ \\
\hline 1 & 29 & 2 & 11 \\
2 & 30 & 1 & 5.6 \\
3 & 33 & 1 & 5.6 \\
4 & 34 & 2 & 11 \\
5 & 35 & 2 & 11 \\
6 & 41 & 3 & 16.6 \\
7 & 42 & 1 & 5.6 \\
8 & 43 & 1 & 5.6 \\
9 & 46 & 1 & 5.6 \\
10 & 47 & 1 & 5.6 \\
11 & 50 & 1 & 5.6 \\
12 & 51 & 1 & 5.6 \\
13 & 52 & 1 & 5.6 \\
\hline
\end{tabular}

Sumber: Data primer hasil penelitian, 2019

Dari Tabel 5 diatas menunjukkan bahwa rentang umur responden atau pembudidaya pembesaran ikan Patin berkisar antara 29-52 tahun. Pada sampel yang berumur 41 tahun mempunyai persentase $16,6 \%$, pada sampel umur 29 , 34,35 tahun yaitu $11 \%$ dan masingmasing sampel dengan persentase yang sama $5,6 \%$ yaitu pada umur $30,33,42,43,46$, $47,50,51,52$ tahun.

Tabel 6. Pendidikan Terakhir Responden

\begin{tabular}{lcc}
\hline Tingkat pendidikan & Responden (Jiwa) & Persentase (\%) \\
\hline SD & 7 & 38,9 \\
SMP & 7 & 38,9 \\
SMK & 3 & 16,6 \\
Perguruan tinggi & 1 & 5,6 \\
\hline \multicolumn{1}{c}{ Jumlah } & 18 & 100 \\
\hline Sumber: Data primer hasil penelitian, 2019 & \\
\multicolumn{1}{c}{ Hasil penelitian menunjukkan } & SD (Sekolah Dasar) dan SMP (Sekolah \\
bahwa tingkat pendidikan akhir setiap & Menegah Pertama) masing-masing \\
pembudidaya berbeda-beda dari Sekolah & sebanyak 38,9\% tingkat SMA (Sekolah \\
Dasar sampai Strara 1. Dilihat dari tingkat & Menengah Atas) berjumlah 16,6\% dan \\
pendidikan maka pada pendidikan tingkat & 5,6\% ialah Perguruan Tinggi.
\end{tabular}


Tabel 7. Lama Usaha Budidaya Responden

\begin{tabular}{|c|c|c|}
\hline Lama Usaha Budidaya (tahun) & Responden (jiwa) & Persentase (\%) \\
\hline 2 & 1 & 5.6 \\
4 & 1 & 5.6 \\
5 & 1 & 5.6 \\
6 & 4 & 22.2 \\
7 & 4 & 22.2 \\
8 & 1 & 5.6 \\
9 & 2 & 11 \\
10 & 2 & 11 \\
12 & 1 & 5.6 \\
15 & 1 & 5.6 \\
\hline Jumlah & 18 & 100 \\
\hline
\end{tabular}

Sumber: Data primer hasil penelitian, 2019

Lama kegiatan usaha budidaya yang telah dilakukan oleh responden dengan total persentase $100 \%$. Pada sampel yang telah melakukan kegiatan usaha budidaya 6 dan 7 tahun dengan persentase masingmasing $22,2 \%, 9$ dan 10 tahun masingmasing $11 \%$ dan $5,6 \%$ pada masingmasing sampel yang berumur 2, 4, 5, 8, 12 dan 15 tahun.

\section{Pengukuran Kualitas Air} Suhu

Berdasarkan data hasil penelitian menunjukkan bahwa nilai suhu pada setiap kolam menghasilkan nilai yang berbedabeda. Perlakuan pengelolaan kualitas air dengan cara pergantian air atau penambahan air serta adanya tanaman air dapat membuat suhu air tetap terjaga selama pemeliharaan. Nilai suhu berkisar antara $27-33^{\circ} \mathrm{C}$, dimana pada pagi hari nilai suhu yaitu $27-28^{\circ} \mathrm{C}$, siang $29-31^{\circ} \mathrm{C}$ dan sore $31-33^{\circ} \mathrm{C}$. Produksi budidaya ikan Patin tumbuh baik pada kisaran suhu $2531^{\circ} \mathrm{C}$ dan kurang cocok di budidayakan di daerah yang dingin (Mahyuddin, 2013). Mahyuddin, 2013 berpendapat bahwa fluktuasi suhu antara siang dan malam tidak boleh lebih dari $5^{\circ} \mathrm{C}$.

\section{$p H$}

Selama pelaksanaan penelitian, nilai $\mathrm{pH}$ media pemeliharaan ikan Patin (Pangasius sp.) berkisar antara $6-8$. Perlakuan pengapuran bertujuan untuk menstabilkan $\mathrm{pH}$ tanah kapur yang biasa digunakan berupa kapur tohor atau kapur dolomit serta penambahan garam ikan pada kolam budidaya juga dapat menstabilkan $\mathrm{pH}$. Semakin rendah $\mathrm{pH}$ tanah dan air, maka kebutuhan kapur akan meningkat. Nilai $\mathrm{pH}$ yang terendah atau kurang dari 7 yang mengindikasikan bahwa suatu perairan bersifat asam terdapat pada kolam akhir pemeliharaan atau siap panen yaitu sebesar 6-7 dan mengalami penurunan dari kolam awal tebar benih. Menurut Mahyuddin (2013), nilai pH untuk budidaya ikan berkisar 6,58.

\section{Analisis Usaha}

Data perhitungan analisa usaha dari setiap responden berdasarkan pengelompokkan ukuran kolam disajikan pada Tabel 8 adalah sebagai berikut : 
Tabel 8. Hasil Penghitungan Analisa Usaha Biaya Produksi Budidaya Ikan Patin di Kecamatan Talang Kelapa

\begin{tabular}{|c|c|c|c|c|c|}
\hline \multirow[t]{2}{*}{ Analisis Usaha } & \multicolumn{5}{|c|}{ Ukuran Kolam $\mathbf{m}^{2}$} \\
\hline & 300 & 400 & 500 & 600 & 800 \\
\hline B. Investasi (Rp) & 25.152 .500 & 18.307 .500 & 37.091 .875 & 20.782 .500 & 34.535 .000 \\
\hline Biaya tetap $(\mathrm{Rp})$ & 1.154 .211 & 837.113 & 1.105 .941 & 488.667 & 1.527 .083 \\
\hline B. Variabel (Rp) & 49.733 .750 & 96.909 .875 & 82.183 .250 & 139.607 .000 & 163.878 .750 \\
\hline Hasil Produksi (Rp) & 5.820 & $8.562,5$ & 9.555 & 12.225 & 15.925 \\
\hline Harga pokok (Rp) & 15.000 & 15.125 & $14.937,5$ & 15.250 & 14.750 \\
\hline Penerimaan (Rp) & 87.300 .000 & 129.375 .000 & 142.721 .250 & 93.562 .500 & 235.212 .500 \\
\hline Pendapatan (Rp) & 18.537 .633 & 31.628 .011 & 59.432 .058 & 46.279 .333 & 69.806 .666 \\
\hline R/C Ratio & 1.71 & 1,41 & 1,81 & 1,33 & 1,56 \\
\hline B/C Ratio & 0.71 & 0,41 & 0,81 & 0,33 & 0,56 \\
\hline BEP Produksi(Rp) & $3.315,58$ & $6.387,75$ & $5.502,03$ & $9.155,39$ & $10.943,46$ \\
\hline BEP Harga (Rp) & $8.537,72$ & $11.442,24$ & $8.633,39$ & $11.425,93$ & $10.203,00$ \\
\hline
\end{tabular}

Seumber: Data primer hasil penelitian, 2019

\section{Biaya Produksi}

Untuk biaya produksi pada usaha budidaya ikan Patin selama penelitian terdiri dari :

\section{Biaya Tetap}

Commited fixed cost

Commited fixed cost adalah jenis biaya yang berhubungan dengan investasi. Biaya investasi berupa pembuatan kolam tanah yang dikeluarkan oleh responden bervariasi besarannya, sesuai jarak atau lokasi kolam dengan jalan dan tekstur tanah kolam. Faktor lainnya yang dapat mempengaruhi nilai investasi adalah penggunaan peralatan pendukung yang digunakan seperti mesin diesel air, paralon dan selang. Rata-rata besaran biaya investasi tertinggi terdapat pada luas kolam $500 \mathrm{~m}^{2}$ sejumlah Rp. 37.091.875 dan terendah pada luas kolam $400 \mathrm{~m}^{2}$ sebesar Rp. 18.307.500.

Descretionary fixed cost

Descretionary fixed cost adalah adalah biaya yang muncul dari keputusan tahunan manajemen yang digunakan untuk membelanjakan biaya tertentu (Rangkuti, 2012). Berdasarkan hasil perhitungan bahwa biaya tetap yang dikeluarkan setiap siklusnya beragam jumlahnya. Hal ini dipengaruhi oleh masa pakai (susut), perlakuan dan perawatan pada peralatan dan kolam. Rata-rata biaya yang dikeluarkan oleh responden untuk usaha budidaya pembesaran ikan Patin tertinggi adalah pada luas kolam $800 \mathrm{~m}^{2}$ yaitu Rp. 1.527.083 dan terendah pada luas kolam ukuran $600 \mathrm{~m}^{2}$ sejumlah Rp. 488.667.

\section{Biaya Variabel}

Biaya variabel yaitu biaya yang jumlahnya berubah-ubah sesuai dengan kegiatan produksi yang dikeluarkan. Total biaya variabel yang dikeluarkan pada usaha budidaya pembesaran ikan Patin tertinggi terdapat pada kolam yang berukuran $800 \mathrm{~m}^{2}$ sejumlah Rp. 163.878.750 dan Rp. 49.733 .750 ukuran kolam $300 \mathrm{~m}^{2}$ terendah. Hal-hal yang dapat mempengaruhinya ialah ukuran kolam, jumlah padat tebar dan harga serta jumlah benih ikan, pakan yang digunakan seperti pakan pabrikan, olahan dan tambahan, penggunaan bahan untuk pengelolaan kualitas air seperti pupuk, kapur dan garam, penambahan pengadaan bahan bakar minyak, upah tenaga kerja dan listrik.

\section{Penerimaan}

Menurut Husni, et al. (2014) penerimaan adalah total pemasukan yang diterima oleh produsen dari kegiatan produksi yang sudah dilakukan yang telah menghasilkan uang yang belum dikurangi oleh biaya-biaya yang dikeluarkan selama produksi. Jumlah penerimaan akan mengalami perubahan seiring jumlah produksi dan penurunan harga jual. Total penerimaan usaha pembesaran budidaya ikan Patin dalam satu siklus tertinggi pada ukuran kolam 800 $\mathrm{m}^{2}$ sejumlah Rp. 235.212.500 dan terendah pada ukuran kolam $300 \mathrm{~m}^{2}$ sejumlah $\mathrm{Rp}$. 87.300.000. 


\section{Pendapatan}

Pendapatan adalah selisih antara penerimaan dengan total biaya produksi yang digunakan selama proses produksi (Soekartawi (1995) dalam Syafruwardi, et al. (2012)). Jumlah penerimaan yang diperoleh dapat dipengaruhi oleh padat tebar, harga benih, jumlah dan kualitas benih, harga hasil produksi, jumlah hasil produksi dan nilai Feed Convertion Ratio seperti pada sampel $\mathrm{C}$ dan sampel 6 sebesar 1,1 dan sampel $\mathrm{H}$ dan sampel $\mathrm{L}$ sebesar 2,1. Pendapatan yang diperoleh dari usaha pembesaran budidaya ikan Patin tertinggi yaitu pada ukuran kolam $800 \mathrm{~m}^{2}$ sejumlah Rp. 69.806.666 dan ukuran kolam $300 \mathrm{~m}^{2}$ sejumlah Rp. 18.537.633 terendah.

\section{$R / C$ Ratio}

Revenue Cost Ratio merupakan salah satu indikator untuk mengetahui kelayakan dalam suatu usaha. Besarnya nilai $\mathrm{R} / \mathrm{C}$ di usaha budidaya pembesaran ikan Patin lebih dari 1. Maka penerimaan yang diterima lebih besar dibandingkan biaya yang dikeluarkan, artinya usaha tersebut layak terus dijalankan (Pebriantari, et al. 2016). Nilai R/C Ratio tertinggi pada ukuran kolam $500 \mathrm{~m}^{2}$ dengan nilai 1,81 dan terendah pada ukuran kolam $600 \mathrm{~m}^{2}$ dengan nilai 1,33. Maka dengan demikian secara keseluruhan dari seluruh responden dinilai mengalami kelayakan usaha.

\section{B/C Ratio}

Benefit Cost Ratio adalah ukuran perbandingan antara pendapatan (Benefit) dengan total biaya produksi (Cost). Besarnya nilai $\mathrm{B} / \mathrm{C}$ pada usaha budidaya pembesaran ikan Patin adalah lebih dari 0. Menurut Rizki, et al. (2017) mengemukakan bahwa usaha yang dijalankan mengalami keuntungan atau layak dikembangkan. Nilai B/C Ratio seluruh sampel dinyatakan bahwa mengalami keuntungan dengan nilai tertinggi yaitu 0,81 pada ukuran kolam $500 \mathrm{~m}^{2}$ dan terendah pada kolam ukuran $600 \mathrm{~m}^{2}$ yaitu 0,33 .

\section{Break Event Point (BEP)}

Menurut Mahyuddin (2013) Break Even Point merupakan analisis yang digunakan untuk mengetahui batas nilai produksi atau volume produksi suatu usaha mencapai titik impas yaitu tidak untung dan tidak rugi. Usaha dinyatakan layak apabila nilai BEP produksi lebih besar dari jumlah unit yang sedang diproduksi saat ini. Sedangkan nilai BEP harga harus lebih rendah dari pada harga yang berlaku saat ini. Berdasarkan data pada Tabel 10 bahwa nilai BEP produksi seluruh sampel lebih besar dari jumlah unit produksi dengan ukuran kolam $800 \mathrm{~m}^{2}$ mempunyai nilai tertinggi yaitu 10.943 $\mathrm{Kg}$ dan terendah pada ukuran kolam $300 \mathrm{~m}^{2}$ sebesar $3.315 \mathrm{Kg}$. Maka semua biaya produksi pada seluruh sampel akan tertutupi bila terjual ikan Patin minimal sebanyak $3.315 \mathrm{Kg}-$ $10.943 \mathrm{Kg}$.

Untuk nilai BEP harga seluruh sampel mempunyai nilai lebih rendah dari pada harga yang berlaku saat ini. Nilai BEP harga Patin terendah berada pada ukuran kolam $300 \mathrm{~m}^{2}$ sejumlah Rp. 8.537 per kg dan ukuran kolam $400 \mathrm{~m}^{2}$ tertinggi sebesar Rp. 11.442/kg. Artinya pada saat harga jual ikan Patin Rp. $8.537 / \mathrm{kg}$ - Rp. $11.442 / \mathrm{kg}$ usaha pembesaran ikan Patin tidak mendapat keuntungan maupun kerugian (impas). Analisis usaha dibuat dengan beberapa asumsi sebagai berikut : tingkat kelangsungan hidup (SR) $75 \%$, waktu pemeliharaan selama 6 bulan/siklus.

Hasil analisis biaya investasi, biaya tetap, biaya variabel, penerimaan, pendapatan, R/C Ratio B/C Ratio dan (BEP) Break Even Point. Menunjukan bahwa kegiatan usaha budidaya pembesaran ikan Patin (Pangasius sp.) di Kecamatan Talang Kelapa Kabupaten Banyuasin layak untuk dilanjutkan dengan berbagai pertimbangan.

\section{KESIMPULAN}

1. Kualitas air pada usaha budidaya pembesaran ikan Patin (Pangasius sp) di Kecamatan Talang Kelapa Kabupaten Banyuasin adalah pada suhu $27-33^{\circ}$ dan $\mathrm{pH}$ pada nilai 6-8.

2. Biaya produksi pada usaha budidaya pembesaran ikan Patin dapat disesuaikan dengan kebutuhan yang diinginkan. Untuk biaya investasi berkisar antara Rp. 18.307.500 hingga Rp. 37.091.875 untuk biaya tetap berkisar antara Rp. 484.667 hingga Rp. 1.527.083 untuk biaya variabel pada kisaran Rp. 49.733 .750 hingga Rp. 163.878.750 per siklus dengan penerimaan antara Rp. 87.300.000 hingga Rp. 
235.212.500 per siklus, pendapatan yang diperoleh yaitu berkisar antara $\mathrm{Rp}$. 18.537.633 hingga Rp. 69.806.666 per siklus dengan nilai analisa $\mathrm{R} / \mathrm{C}$ ratio lebih dari 1, B/C ratio lebih dari 0 dan Nilai BEP produksi antara $3.315,58 \mathrm{Kg}$ hingga 10.943.46 Kg dan BEP harga berkisar antara Rp. 8.537,17 hingga Rp. 11.442,24 untuk mendapat keuntungan dan tidak mengalami kerugian (impas).

\section{DAFTAR PUSTAKA}

Badan Pusat Statistik Kabupaten Banyuasin, 2017. Kabupaten Banyuasin Dalam Angka. BPS Kabupaten Banyuasin.

Badan Pusat Statistik Kabupaten Banyuasin, 2018. Kecamatan Talang Kelapa Dalam Angka. BPS Kabupaten Banyuasin.

Dinas Perikanan Banyuasin, 2017. Pengelolaan Kawasan Perikanan Budidaya.Darihttp://diskan.banyuasi nkab.go.id/2017/04/28/pengelolaanka wasanperik anan-budidaya (10 Februari 2019).

Ghufran, M. 2010. Budidaya Ikan Patin Di Kolam Terpal. Andi Offset. Yogyakarta.

Husni, A., K. Hidayah, Maskan. 2014. Analisis Finansial Usahatani Cabai Rawit (Capsicum frutescens) di Desa Purwajaya Kecamatan Loa Janan. Jurnal ARIFOR. 13 (1) : 49-52.

Kementrian Kelautan dan Perikanan, 2018. Industri Patin Indonesia Rebut Pasar Global. Dari (https://kkp.go.id/arti kel/3163-industri-patin-indonesiareb ut-pasar-global (17 April 2019).

Mahyuddin, K. 2013. Panduan Lengkap Agribisnis Patin. Penebar Swadaya. Jakarta.

Pebriantari, N. L. A., I. N. G. Ustriyana, dan I. M. Sudarma. 2016. Analisis Pendapatan Usahatani Padi Sawah Pada Program Gerbang Pangan Serasi Kabupaten Tabanan. EJournal Agribisnis dan Agrowisata. 5 (1) : 111.

Rangkuti, F. 2012. Studi Kelayakan Bisnis Dan Investasi. IKAPI, Jakarta.

Rizki. M, Elfiana, Satriawan. H. 2017. Analisis Usahatani Pisang Ayam Di Desa Awe Geutah Paya Kecamatan Peusangan Siblah Krueng Kabupaten Bireuen. Jurnal S. Pertanian 1 (3) : $187-186$

Suratiah, K. 2015. Ilmu Usahatani Edisi Revisi. Penebar Swadaya. Jakarta.

Syafruwardi, A., H. Fajeri dan Hamdani. 2012. Analisis Finansial Usahatani Padi Varietas Unggul Di Desa Guntung Ujung Kecamatan Gambut Kabupaten Banjar Kalimantan Selatan. Jurnal Agribisnis. 2 (3) : 181192.

Triyanti, R. dan Hikmah. 2015. "Analisis Kelayakan Usaha Budidaya Udang Dan Bandeng: Studi Kasus Di Kecamatan Pasekan Kabupaten Indramayu". Buletin Ilmiah "MARINA" Sosial Ekonomi Kelautan dan Perikanan Vol.1 No. 1 Tahun 2015: 1-10. 